vided at student orientations.

21. "Report Cites High-Tech Cheating at UC," San Francisco Chronicle, 8 February 1986.

22. UCLA publishes an annual Teacher's Guide for faculty with sections defining academic dishonesty and outlining the university's procedures for handling cases. I did not read this guide until 1 sat down to edit this essay.

23. At Berkeley, the most common sentence is up to 30 hours of community service, the next most common is suspension for one semester. "Report Cites High-Tech Cheating at UC," San Francisco Chronicle, 8 February 1986.

24. Some institutions resist doing so for fear that it will somehow convey the "wrong" message to its incoming students. I do not subscribe to this opinion.

\section{References}

Barnett, David C. and Jon C. Dalton. 1981. "Why College Students Cheat," Journal of College Student Personnel (November): 545-51.

Bushway, Ann and William R. Nash. 1977. "School Cheating Behavior," Review of Educational Research 47: 623-32.

Chisholm, Donald. 1990. "Between Leibnitz and Voltaire: Exams and Grading in a Less than Perfect World," PS 23: 600-04.

Haines, Valeri J., George M. Diekhoff, Emily E. LaBeff, and Robert E. Clark. 1986. "College Cheating: Immaturity, Lack of Commitment, and the Neutralizing Attitude," Research in Higher Education 25: 342-54.

Hawley, Christopher S. 1984. "The Thieves of Academe: Plagiarism in the University System," Improving College and University Teaching 32: 35-39.

Jendrek, Margaret Platt. 1989. "Faculty Reactions to Academic Dishonesty," Journal of College Student Development 30: 401-06.

Johnson, Charles D. and John Gormly. 1972 "Academic Cheating: The Contribution of Sex, Personality, and Situational Variables," Developmental Psychology 6: 320-25.
Leming, James S. 1978. "Cheating Behavior, Situational Influence, and Moral Development," Journal of Educational Research 71: 214-17.

Steininger, M., R. E. Johnson, and D. K. Kirts. 1964. "Cheating on College Examinations as a Function of Situationally Aroused Anxiety and Hostility," Journal of Educational Psychology 55: 317-24.

\section{About the Author}

Donald Chisholm is an assistant professor in the department of political science at the University of California, Los Angeles, and a frequent contributor to $P S$.

\title{
The Comparative Study of Constitutions: Suggestions for Organizing the Inquiry ${ }^{1}$
}

\author{
Donald L. Robinson, Smith College
}

Americans have a special incentivealmost a vocation - to understand constitutionalism. The United States was the first modern nation to base its government on a written constitution. Ever since the founding, the Constitution has had a unique place in the nation's consciousness. It has been the adhesive of American nationality. Not land (our territory has changed over the years), not blood (we are all immigrants), but a commitment to the Constitution binds us together. The Constitution is a symbol for what makes us a nation: a shared commitment to government by consent, its powers enumerated, checked and balanced, its commands articulated in a rule of law.

Recent developments around the world have highlighted the tension between constitutionalism and democracy. ${ }^{2}$ Ever since its founding as an independent nation, America has been committed to both, though in varying degrees. The commitment to democracy was set forth in the Declaration of Independence and the Gettysburg Address. The commitment to liberty, established in a written constitution and in bills of rights and defended by a powerful legal community, goes even deeper. For Americans, democracy is a quest, of varying intensity; constitutional government is the steady commitment.

The American commitment to constitutionalism is not only deep and proprietary; it is confident. We often quote Gladstone's aphorism about our constitution being the "most wonderful work ever struck off at a given time by the brain and purpose of man." There have been problems in American life over the years, and to correct some of them, we have had to amend the Constitution. The basic framework endures, however, and we believe it confirms the wisdom of its framers. ${ }^{3}$

In light of our own experience and our sense of ourselves as a "city on the hill," it has seemed perfectly natural for Americans to take a special interest in constitutionmaking in other countries. Some of our intellectuals have insisted that constitutions are cultural artifacts, and that it is as foolish to try to transplant our Constitution to alien settings as it would be to import constitutional arrangements from abroad. ${ }^{4}$ Over the years, however, some American lawyers and political scientists have operated on different assumptions. In Latin America during its several epochs of constitutionmaking, in Japan and Germany following World War II, in Africa as the shackles of colonialism were broken in the 1960s, Americans have been willing to give advice and lend a hand in preparing drafts. ${ }^{5}$

The Bicentennial of the Constitution stimulated some reflection on these efforts. So did the drive of many nations in the Third World-in Latin America, Africa, and Asia-to throw off repressive regimes and embark upon the quest for more 
democratic governance.

Sensing the need for an interdisciplinary, international inquiry into this phenomenon, the American Council of Learned Societies (ACLS) mounted a Project on Comparative Constitutionalism in 1989 and 1990. In Uruguay, Zimbabwe, Thailand, Berlin, and Hungary, scholars and political leaders from many nations attended a series of institutes, giving papers and engaging in a spirited exchange of views.

It is safe to say that those who conceived and supported this project, and those who assumed responsibility for its implementation, had no idea how timely it would turn out to be. It was mounted because people thought it would be valuable for Americans to view their own constitutional tradition comparatively and because people thought constitutionmakers in other parts of the world, particularly the Third World, might benefit from a comparative perspective on their efforts.

The ACLS project is winding down now, but events around the world that have given it such importance are proceeding apace. Both at home and abroad there is heightened interest in constitutional questions: the sense among thoughtful Americans that governance here is straining in the face of modern challenges and would benefit from a searching critical analysis; the sense in the Third World that the state must be strengthened and at the same time be made more accountable to the people and more sensitive to human rights; the sense in Eastern Europe that both the state and the economy must be liberalized, but without unendurable suffering and reckless sacrifice of communitarian values.

These concerns draw Americans and people in other nations toward a common conversation about the nature of constitutionalism.

\section{Current Efforts}

Besides the ACLS project, there have been other notable efforts to promote the comparative study of constitutions. The Bicentennial of the United States Constitution occasioned several of them. The American Enterprise Institute held a conference on constitution-making in eight nations (France, Greece, USA, Yugoslavia, Spain, Egypt, Venezuela, and Nigeria), and another on federalism in eight nations (India, USA, Belgium, Canada, Switzerland, Spain, Malaysia, and Yugoslavia). ${ }^{6}$ In 1989, Columbia University Law School concluded a study of "the influence of the U.S. Constitution abroad" with the publication of a volume of papers focusing on the protection of rights under various constitutional governments. ${ }^{7}$ Since then, Columbia has sponsored a number of dialogues with constitutionalists in Africa and China. Last March, the law school at Emory University held a symposium on comparative constitutionalism; several papers and commentaries were published in Emory Law Journal (Summer 1991).

Some studies have had an even broader focus. This year Brookings will publish a volume, entitled $D o$ Institutions Matter?, edited by Kent Weaver and Bert Rockman. The book presents case studies comparing the performance of presidential and parliamentary governments (mainly the United States and Great Britain) in dealing with environmental protection, energy, military policy, entitlements, and other issues. Also noteworthy is a book by Klaus von Beyme, of the University of Heidelberg, Germany, entitled America As a Model: The Impact of American Democracy in the World (New York, 1987). Von Beyme's book, focusing especially on the presidential system of government, federalism and judicial review, is particularly valuable for its citation of foreign-language (mostly European) sources on the subject.

The quality of critical studies of the American system of governance has also improved in recent years, in part as a consequence of attentions focused by the Bicentennial. During the 1980s, owing in large measure to writings by Lloyd Cutler and James L. Sundquist, ${ }^{8}$ people began to think in new ways about a new tendency in American governance toward "divided government," that is, control of the White House and at least one house of Congress by different parties. This fall, David Mayhew, of Yale's political science department, published a highly skeptical assess- ment of the Cutler-Sundquist argument, entitled Divided We Govern (Yale University Press, 1991), challenging the notion that the national government is more productive when the branches are controlled by the same party. The Politics of Divided Government (Westview Press, 1991), edited by Gary W. Cox and Samuel Kernell, examines the causes (not all electoral) and effects (particularly egregious in fiscal and monetary affairs) of divided government and puts the phenomenon in comparative context by examining earlier periods of American history and the situation at the state level. ${ }^{9}$ The argument about divided government is far from over, but it has clearly moved to a new plane.

Even textbooks for courses in American national government reflect a growing sophistication and willingness to analyze the American system comparatively. A good example is The Challenge of Democracy, by Kenneth Janda, Jeffrey M. Berry, and Jerry Goldman. The text draws heavily on Janda's multinational comparison of party systems and includes a feature sprinkled throughout the book, entitled "Compared With What?" 10

Besides the U.S. Bicentennial, the other great stimulus to a comparative analysis of political systems is of course the series of revolutions that swept the world in the late 1980s. American professors of law, economics, political science and history have leapt into the fray, eager to contribute what they know to the development of democratic institutions, particularly in Eastern Europe.

What has been lacking in this intellectual rejuvenation, however, has been an institutional commitment to the study of constitutionalism and constitutions. There is at least one notable exception: a project at the University of Chicago, directed by political scientist Jon Elster, that aims at maintaining an archive (or "databank," as they call it) of documents relating to the framing of new constitutions in seven countries (Albania, Bulgaria, Czechoslovakia, Hungary, Poland, Romania, and Yugoslavia) and developing methodologies for analyzing this vast body of material. Noting that events in the region present a "unique opportunity 
for comparative analysis [of the] recasting of political and legal institutions," the investigators will use the materials to answer questions about constitution-making in general. Its "databank" alone justifies the project; it will be enormously valuable to scholars, both within and outside the Chicago project. The Spring 1991 issue of The University of Chicago Law Review, entitled "Approaching Democracy: A New Legal Order for Eastern Europe," contains articles by Gerhard Casper, Jon Elster, Akhil Reed Amar, Lloyd Cutler and Herman Schwartz, Andrzej Rapaczynski and Cass Sunstein, among others, displaying some of the firstfruits of this effort.

There is, however, one major limitation to the Chicago project. It is confined to the seven nations of Eastern Europe. It is also guided by the concern of Western scholars to understand what is happening in Eastern Europe. The organizers explicitly eschew any intention of lending assistance to political leaders in Eastern Europe in their constitution-framing efforts. No doubt scholars associated with the Chicago project will have occasion to make suggestions to their contacts in Eastern Europe. The design of the project does not lend itself, however, to the generation of solutions to practical political problems. ${ }^{11}$ That is not meant in criticism of the Chicago project, but it does tend to distinguish it from the effort called for in these pages.

\section{The Challenge}

Current developments in Latin America, Africa, and Europe, and to a lesser extent in Asia, present a great challenge to those who place their faith in constitutional democracy. People want self-government. They mistrust authoritarianism and resent hegemony. They long to establish governments that can promote a decent standard of living while respecting basic rights, governments capable of protecting them from outside control and internal violence.

Meanwhile, intellectuals around the world seem ready for approaches that are genuinely interdisciplinary and comparative. There seems to be a new openness to the possibility of valuable insights from other cultures and other disciplines than one's own. It is the odd American now who goes to other countries in a spirit of bearing the truth. Intellectuals are sensitive to the value of other cultures and aware that institutions are rooted in those cultures. There is a fascination with how other systems work and with what we might learn about ourselves by examining the dialectic of cultures and institutions in other settings. The study of constitutionalism offers an opportunity to focus these concerns on a topic that is both comprehensive and fundamental.

Written constitutions are a relatively recent phenomenon in the history of nations, but they are now widely accepted as part of the essential

\section{If we cannot help poor} nations improve their

\section{governance, we cannot help them at all.}

equipment of a modern nation. ${ }^{12}$ Yet constitutionalism bears many interpretations, and constitutions take many forms. Every nation, including the United States, has much to learn about the subject. ${ }^{13}$

For those considering whether or not Americans might have something to contribute to the world's quest for improved forms of democratic governance, two questions need to be distinguished:

- where do the cultivation of a spirit of constitutionalism and the drafting of a constitution rank among a new nation's needs? and

- how ought we to prepare ourselves to assist in this process?

On the first question, Americans who forget their own history need to be reminded that drafting constitutions is not necessarily the first thing a nation needs to do. In our own case, we did not adopt the Articles of Confederation until March 1781, and the government it established was judged a dismal failure. The Convention that drafted our enduring Constitution did not convene until 11 years after the Declaration of Independence, and it was another year and a half before the Constitution was ratified by the states. Only then did the elite, pressed hard by a clamorous populace (what James MacGregor Burns has called "cobblestone democracy"), turn to the drafting of a bill of rights. The Supreme Court did not assert the power of judicial review until 1803 and did not exercise it a second time until 1857, 70 years after the framing.

Japan is another example. The Meiji Restoration took place in 1868. The leaders of the new Japan spent two decades reorganizing the landholding system, disarming the samurai, reforming the schools, building a modern army, developing the rudiments of a party system, reconstituting local government and revising the cabinet system, before they turned to drafting a constitution. ${ }^{14}$ By 1889 , more than three decades after the Restoration, they were finally ready to commit themselves to a written constitution.

Modern nations may not have the luxury of waiting so long. For one thing, popular demands for democracy are more insistent than they were in the days when liberal constitutions emerged from the competition of elites. Though the point is often made in an exaggerated way, it is true that Japan's culture is more amenable to discipline than many in the world today. By contrast, today's new governments need legitimacy both acutely and urgently; adopting a constitution seems an essential part of the strategy for gaining it. ${ }^{15}$ But when new nations stumble in these first attempts, we ought to recall our own early history.

Despite these ample grounds for modest expectations, people are beginning to understand that effective, accountable government is a true priority, even in the most desperately poor parts of the globe. It used to be held that democracy required a minimum of material wellbeing, and accordingly that the first priority was to lift the standard of living in developing nations. We now realize that aid funnelled through corrupt, ineffective regimes rarely reaches its intended recipients. If we cannot help poor nations improve their governance, we cannot help 
them at all.

How can outsiders help the people of these regions in the quest for such governance? This is a relatively new question in human history. Colonial powers were interested in the governance of these regions, but their goal was control. Some Americans and other outsiders still have colonial instincts, but we proceed here on the assumption that a substantial number of people want to help people in other lands toward self-government. How can they be of assistance?

The response must be dialectical. On one hand, it must take guidance from voices in the affected regions. It must reflect a deep and sympathetic understanding of the region's culture. On the other hand, it must proceed from a profound and selfcritical understanding of the spirit of constitutionalism and the ways in which that spirit has been embodied in various forms of governance.

The elements of such an understanding are present in America, but they are not well focused on the comparative study of constitutionalism. In institutions of higher learning (universities, research institutes, foundations), scholars pursue research in area studies. Some of these efforts are interdisciplinary; some are comparative. But none that I am aware of focuses on the comparative study of constitutionalism. A partial exception can be found in the project at the University of Chicago, to which I have already referred, and at certain law schools, where specialists focus on the study of legal systems. Few, however, if any of these are broadly comparative, and fewer still genuinely interdisciplinary. ${ }^{16}$

If it is true that the elements of the field are present in American research institutions, what is neededequally for the sake of American assistance to new nations and to encourage the development ${ }^{17}$ of a neglected field of study-is to pull them together and focus them on the subject of constitutional governance.

How might this be done?

Let us begin by citing several aspects of the need, then consider how to proceed to meet these requirements. (To avoid the passive voice, I will use the pronoun "we," though I intend no assumption that any specific institution has a particu- lar responsibility here. I write of needs, not who should meet them.)

\section{Institutional Needs}

1. We need a place that can promote interdisciplinary dialogue involving scholars in the law, the humanities, and the social sciences (particularly political science and history), and including area specialists.

2. We need a place that can edit and publish a scholarly journal, and perhaps a newsletter describing the progress of constitution-writing efforts around the world and the involvement of Americans (and other consultants) in these efforts.

3. We need a place that can help to train graduate students and other young scholars, both foreign and American, in the comparative study of constitutions.

4. We need a place that can involve both scholars and a wide range of practitioners (political leaders, lawyers and judges, journalists, civic educators) in its activities.

\section{Substance of the Inquiry}

In defining the subjects of inquiry for a center on the comparative approach to constitutionalism, we need to stay close to political events. The subject has a philosophical dimension, but it needs to be anchored in political and cultural reality. Indeed, that is its power and fascination, that it operates in the zone between theory and practice, drawing the two together.

Taking cues from recent events, it is possible to illustrate the kinds of questions that might be addressed.

1. Woodrow Wilson's vision of a world "safe for democracy" was plagued by the problem of selfdetermination. By 1963, John F. Kennedy had retreated to the notion of a world "safe for diversity." A century of world wars and liberation struggles shows how difficult it has been to achieve even Kennedy's modest goal. In the Czech and Slovak Federal Republic and the former Soviet Union, in Ethiopia and Sri Lanka, in Canada and Peru, nation-builders are still trying to find ways to forge a measure of unity in the face of profound ethnic and cultural conflicts.

Many people believe that the answer lies in distributing functions within a federal union. There are many models and some successes, but the problem remains one of the most difficult challenges for constitutionalists. Which are the minimum functions that must be performed by the center, which are best delegated to the periphery, and how can the distribution be monitored, and how can governance be kept accountable amid such complexities?

2. By what stages can constitutional ideals be achieved? Many people in Central Europe, and many outside advisers, believe that democratic governance requires free markets. The paradox is that the conversion to free markets seems to require strong state intervention. How can an accountable government, committed to human rights, deal with the resistance of those who will inevitably be hurt by the conversion? In Africa, in the Middle East and Northern Ireland, and in many parts of Asia, ethnic conflicts make it very difficult to achieve consensus on structures and processes of government. Is it possible in such circumstances to establish governments strong enough to keep the peace, without endangering vital rights? By what stages ought nation-builders to proceed?

3. In the United States, constitutionalism has been closely tied to liberalism and the rule of law. In other cultures, individualism is less well engrained and communitarian ideals more highly valued. Is it possible to disentangle constitutionalism from its liberal affinities and ground the quest for accountable governance in other principles? A Westerner hardly knows how to formulate this problem, but a dialogue between heirs of Judeo-Christian culture and those of Islamic, Buddhist, and Hindu background might point the way to more universal ideals.

4. We also need a more particular dialogue on human rights and judicial protection. Some Americans are suspicious of attempts to "guarantee" social and economic rights, fearing that we may jeopardize civil and political rights by stretching the analogy too far. Others insist that 
equality is an integral part of the constitutional ideal and must be kept alive, if we are to nurture a commitment to constitutionalism, especially in the Third World. This debate, including a consideration of alternative strategies for guaranteeing a minimum standard of material well-being, is an urgent part of the modern debate over constitutionalism.

5. Finally, there are questions about the structure of government and modes of representation and accountability. Latin American and Eastern European nations are trying to decide between presidential and parliamentary models, or some combination. Should powers of rulemaking, enforcement, and administration be fused or separated? Should the electorate choose a representative assembly, to whom the work of forming and monitoring a government is delegated? Or should voters choose multiple authorities, to whom differing responsibilities are assigned, and whose performance in office is subject to mutual checks? Which system offers the best promise for control over such functions of governance as the armed forces or the banking system? How ought electoral laws be fashioned, to achieve various goals of representation in differing circumstances?

These are merely examples of the kinds of inquiry that constitutionalists must address. To define them, even in this preliminary way, is to demonstrate the need to engage the attention of social scientists and jurists, politicians, practicing attorneys and journalists, philosophers, theologians and anthropologists, and to invite participation by people from all over the world.

How might such an interdisciplinary, comparative inquiry be initiated? Who can assume responsibility for its organization? It needs to attract scholars from many fields: theorists, to lead critical consideration of the ideas that underlie constitutionalism; anthropologists and students of religion, to examine the cultures that have supported or opposed constitutionalism; legal scholars, to explain the various forms that constitutional guarantees can take; historians, to trace the rise (and disintegration) of the constitutional ideal in different settings; economists, to analyze the role of markets in constitutional regimes. The inquiry needs somehow to stay in touch with practical affairs, with the work of men and women who are struggling to realize the promise of effective, accountable government in diverse circumstances.

Separate colleges and universities can invigorate their curricula by focusing interdisciplinary efforts on constitutional studies, but none by itself has sufficient resources to have much impact (save perhaps in curricular development) on the field in general.

Perhaps the professional associations (the American Political Science Association, American Historical Association, Association of American Law Schools, and others, in conjunction with their international counterparts) can play a role. The councils of these associations are broadly representative. A carefully considered resolution by them to support such an initiative might have considerable impact.

Leading research institutes, by committing themselves to a longrange, interdisciplinary assault on these questions, may also be able to make a significant contribution.

\section{Conclusion}

The present historical moment is full of opportunity and full of danger. Machiavelli wrote, "There is nothing more difficult to carry out, nor more doubtful of success, nor more dangerous to handle, than to initiate a new order of things." To this grave insight, so full of challenge to political leaders in the new nations, Abraham Lincoln added another for his own compatriots, in his remarkable speech to the Young Men's Lyceum in Springfield, Illinois, in 1838. Self-government, he pointed out, once established, must still be defended from the ravages of complacency and ambition. At a time when lynch-mobs were threatening to tear down the fabric of liberty in America, Lincoln urged that our surest defense lay in making "reverence for the constitution and laws ... the political religion of the nation." A quarter-century later, Lincoln learned that our redemption lay in transcending those very laws.
Nations must decide for themselves whether framing and implementing a new constitution is a priority. Americans, in relating to other nations, must remember that, in our own history, the achievement of constitutional ideals has been fitful and that we still have a lot to learn. As Walter Murphy reminds us in his " Recessional Reflections," our tendency to equate constitutionalism with liberalism and with the rule of law is much too facile.

There is no better way to deepen our own understanding of constitutional ideals than to enter into dialogue with people from other cultures and traditions. We would all benefit if this inquiry were broadened, deepened, and sustained.

\section{APPENDIX \\ A Brief Survey of American Involvement in Constitution- Making and Regime-Building Abroad}

The first thing to say about the recent spate of activity involving Americans in constitution-making abroad is that it focuses mostly on Eastern Europe-not Germany, and not the Soviet republics, but the nations between, nations that were, until recently, satellites of the Soviet empire. ${ }^{18}$ This is so partly, I suspect, because these nations have been, at least in the early stages of their liberation from Soviet control, so unreservedly eager to adopt Western (though not necessarily American) practices and to enter the community of European and North Atlantic nations. Another factor is that Americans jump at the chance to solidify their "victory" in the Cold War. It seems a lot easier to build political cultures capable of sustaining democratic governance in these relatively familiar climes than to find a basis in the Koran, or in the radical diversity of cultures in Asia or Africa, for constitutionalism as we understand it. ${ }^{19}$

\section{Joint Ventures}

As the nations of Central and Eastern Europe in 1989 began to build independent governments, legis- 
lators in the region soon realized that they would have to learn a new craft. Responding to this need, staff of The Ford Foundation, joining with colleagues from the European Cultural Foundation, convened a planning meeting in Vienna in the spring of 1990, attended by legislators from Czechoslovakia, Hungary, Poland, and the Soviet Union, as well as parliamentarians and scholars from Western Europe and the United States. The meeting defined the need for technical assistance, advice, and support services and formed a steering committee, headed by Gerhard Loewenberg, a political scientist from the University of Iowa, and JeanPierre Worms, member of the French National Assembly and the Parliament of Europe.

The initiative at Vienna resulted in a series of workshops and parliamentary exchanges focused on the practice of legislating in democratic systems, as well as cross-national seminars on federalism. (Other American foundations, including the Pew Charitable Trust, Mott, the Rockefeller Brothers Fund, and the German Marshall Fund, joined in supporting these efforts.) In September 1990, the East-West Parliamentary Practice Project was launched at The Hague. Scholars and legislators from Czechoslovakia, Hungary, Poland, the Soviet Union, Lithuania, and Bulgaria, as well as the Netherlands, Great Britain, Germany, Austria, Spain, and the United States, debated principles of democracy and legislative practice. Subsequent workshops in Eastern Europe have focused on the committee system, rules of debate, voting procedures, information resources, and other practical concerns of legislators. The Project continues, though rapidly changing circumstances in the region have required alert adaptation. ${ }^{20}$

\section{U.S. Government Agencies}

In April 1990, Speaker Thomas Foley of the U.S. House of Representatives named a Special Task Force on the Development of Parliamentary Institutions in Eastern Europe, chaired by Representative Martin Frost (D-TX) (staff director:
Kristi Walseth). It has provided support for the Congressional Reference Service at the Library of Congress (LC:CRS) to assist legislatures in Hungary, Poland, Czechoslovakia and Bulgaria (they may add the Baltic nations soon). The program provides equipment that enables modern legislatures to work effectively (copiers, fax machines, computers, telecommunications equipment); sends books and periodicals to stock parliamentary libraries; and gives technical assistance on legislative organization and procedures. In the maelstrom of advice and support being directed at Eastern Europe, the ability to provide material support has enabled the Special Task Force to play a special role. ${ }^{21}$ The Task Force, reinforced by the Association of Former Members of Congress, has also offered consultation about legislative organization and procedures, and the LC:CRS has received delegations of parliamentarians from Eastern Europe eager to see how our Library supports the law-making process.

The U.S. Agency for International Development (AID) has been another major source of assistance to the new democracies of Eastern Europe, providing grants to SUNY-Albany (\$850,000; Abdo Baaklini, director) to provide training, consultation, and public policy analysis to the Hungarian legislature; and to the National Endowment for Democracy (NED) to conduct programs in support of democratic institutionbuilding and civic education in Poland and Hungary. NED has, in turn, made grants to both national political parties and to the U.S. Chamber of Commerce and the AFL/CIO for programs dealing with the conversion to a free-market economy and free trade unions, the electoral process, political organization, and the establishment of a free press.

The Law and Social Science division of the National Science Foundation has funded a major investigation of democratic values in the former Soviet republics. Directed by James Gibson, of the University of Houston, the project will use survey techniques to gauge the support for democracy and constitutional government in the former Soviet Union.

\section{Consultants}

Closer to home (that is, to constitutionalism per se), perhaps the most significant effort has been the American Bar Association's Central and East European Law Initiative (CEELI) (staff director: Mark Ellis). CEELI has provided American legal expertise and assistance to countries in Eastern Eurpe that are modifying or restructuring their laws or judicial systems. Their work thus far has centered on Poland, Bulgaria, Romania, and Albania. In consultation with "government and nongovernment officials, legal scholars and practitioners" in the region, CEELI dispatches small groups of lawyers and judges (three to five persons) ${ }^{22}$ to conduct workshops for political and governmental leaders engaged in legal reforms. Efforts have focused on technical assistance: drafting constitutions, creating an independent judiciary, and reforming criminal laws.

CEELI's response to constitutionframers in Albania illustrates their approach. The People's Assembly of Albania sent CEELI a copy of their draft-constitution, dated March 1991, along with a copy of their interim constitution. On August 25-28, 1991, Homer Moyer, chair of the CEELI Board, travelled to Albania for discussions with politicians there, and they agreed that an analysis of the constitution would be the first step. The draft was then sent by mail to a panel of American experts, twentythree of whom (including five federal judges, three state court judges, ten law professors, two congressional staffers, and Louis Fisher, of LC:CRS) responded in writing. Some of the responses were quite detailed, and some rather blunt. They ranged from comments about the dangers of entrusting too much power to a legislative assembly, ${ }^{23}$ to suggestions about how to phrase human rights guarantees and fortify the independence of the judiciary, to such matters as property ownership and the regulation of political parties. A delegation travelled to Tirana, Albania, on October 7-11, 1991, for an intensive workshop on these matters. The visit included a "seminar" on the separation of powers given by Louis Fisher to a packed auditorium of law 
school students, many of whom were apparently familiar with his books on the subject.

CEELI has also provided technical assistance on Bulgaria's law concerning the ownership and use of agricultural lands, commercial law and foreign investment codes, on Romania's proposed legislation and on the organization of the judiciary, and on Poland's draft constitution. It is mounting a Sister Law School program, pairing each law school in the region with at least three American law schools. The program began with workshops in Poland and Yugoslavia and a visit to the United States in September 1991 by 20 law school deans from Eastern Europe. It is expected to include exchanges of faculty and students, joint research projects, and assistance in library development, curriculum reform, and law school administration.

CEELI offers the following comment on its approach:

U.S. legal experience and traditions offer but one approach that participating countries may wish to consider. A variety of models, including those of many civil law countries, offer alternative legal traditions that are also valuable sources of law. In the emerging democracies of Central Europe there is, however, great interest in the U.S. legal experience, particularly with regard to individual and human rights, allocations of governmental power, and the free market system.

By drawing on the resources of the American Bar Association, CEELI has been able to marshal a high level of expertise for service in countries that have requested such assistance. In a highly focused way, it seems to have made a substantial contribution. ${ }^{24}$

In 1990, the Ford Foundation made a grant to Columbia University to provide technical assistance for the constitutional drafting committee of the Polish Parliament. Under the direction of Andrzej Rapaczynski, professor of constitutional law at Columbia Law School, the project responded to an urgent request for assistance by Solidarity's Civic Parliamentary Club and members of the parliamentary committee charged with drafting a new constitution. The grant supported consultations (some by correspondence) between Ameri- can and European scholars and legal experts, including some from other countries of Eastern Europe; and it planned to assist libraries in acquiring publications on comparative constitutional law not currently available in Poland. ${ }^{25}$

Of potentially broader significance, but thus far focused mainly on Europe, is the Research Committee of Legislative Specialists (RCLS), formed at the July 1991 World Congress of the International Political Science Association in Buenos Aires, Argentina. Chaired by Lawrence Longley of Lawrence University and Allan Kornberg of Duke University and with a board consisting of political scientists from Argentina, Denmark, the United Kingdom, Italy, New Zealand, Nigeria, Turkey, and the United States, RCLS intends to publish a newsletter summarizing research on comparative legislative practices and is planning to cosponsor, with the Centre for Research on Constitutional Right, of the University of Paris, an international research workshop on the role of legislatures and parliaments in newly democratic regimes. The workshop is tentatively planned for Paris in early 1993.

\section{Clearinghouses}

Two groups are presently serving as clearinghouses for consultations by Americans in Eastern Europe. The Congressional Reference Service at the Library of Congress is publishing an occasional newsletter, called Parliamentary Development. The first issue, published on July 31, 1991 , presented 15 pages of notes on consultative and support projects in Eastern Europe and the Soviet Union. There were separate listings for multinational activities and those aimed at particular countries.

Meanwhile, the American Political Science Association (APSA) is gathering information about activities by political scientists in Eastern Europe for publication in its quarterly magazine, $P S$. The first list will report such projects as visits by Samuel Patterson of Ohio State University, Gerhard Loewenberg of the University of Iowa, and John Hibbing of the University of Nebraska to Hungary to engage in consulta- tions about legislative practices. Other political scientists report that they have been assisting with constitution-writing in Yugoslavia, Russia, and Latvia.

\section{European Efforts}

This survey does not intend to report on efforts by non-Americans in constitution-framing, but it should be noted at least in passing that Western Europeans are engaged in a wide variety of activities in this arena, too. For example, Antonio La Pergola and Wolfgang Zeidler, former presidents of the Italian and West German constitutional courts, have established a Center for the Study of Judicial Review. ${ }^{26}$ Further, The Hansard Society for Parliamentary Government has organized a Democratic Advisory Service, a group of experts on governance issues, to be made available, with the support of the Foreign and Commonwealth Office's "Know-How Funds," to new democracies. The Society also entertained two delegations of Polish parliamentarians in 1990.

\section{Notes}

1. This paper draws on my report for The Ford Foundation, assessing the recent Project on the Comparative Study of Constitutionalism, administered by the American Council of Learned Societies. I am particularly grateful to Shepard Forman for his support and encouragement.

2. The complex relationship between constitutionalism and democracy is analyzed by Walter F. Murphy, "Constitutions, Constitutionalism, and Democracy,' to be published in Douglas Greenberg, Stanley Katz, and Steven Wheatley, eds., Constitutionalism and Democracy (New York: Oxford University Press, forthcoming in 1992).

3. Other nations would of course contest the view that Americans have any special proprietorship over constitutionalism, and with good reason. Framers in the newly independent nations of Eastern Europe, for example, seem to be looking for inspiration and guidance as much to Germany and France, not to mention their own histories, as they do to the United States.

4. This whole question of constitutional borrowings is only dimly understood. Fred Riggs has shown how dismal has been the experience of Latin American countries that have tried to adopt the presidential system on the North American model. We tend to believe that a constitution, to succeed, must grow naturally out of the soil of a nation's political experience. On the other hand, there 
is the example of Japan's relatively positive experience over the past forty-odd years with a constitution imposed by a conquering army bent on radical reform.

5. Remarkably the history of American involvement in constitution-making abroad has never been told in any adequate way. Carl J. Friedrich provides a sketch, in a slender volume of lectures entitled The Impact of American Constitutionalism Abroad (Boston University Press, 1967), but it focuses on the idea and forms of American constitutionalism, rather than the efforts of Americans to carry these ideals abroad. Louis Henkin and Albert Rosenthal have edited a collection of essays on the topic (Constitutionalism and Rights: The Influence of the United States Constitution Abroad [Columbia University Press, 1990]), some addressed to "ideas and institutions," others treating particular countries (Germany, Japan and Korea, the Philippines, Poland, sub-Sahara Africa and South Africa), and one, by Henkin, on international human rights. There are, of course, other useful books and articles on American involvement on framing efforts in specific countries (for references, see the bibliographical essay by Andrzej Rapaczynski, published in the Henkin and Rosenthal volume). But I know of no major comparative or analytical work on this subject, treating the phenomenon in general.

6. Robert A. Goldwin and Art Kaufman, eds., Constitution Makers on Constitution Making (AEI, 1988); and Robert A. Goldwin, Art Kaufman, and William A. Schambra, eds., Forging Unity Out of Diversity (AEI, 1989).

7. Louis Henkin and Albert J. Rosenthal, eds., Constitutionalism and Rights: The Influence of the United States Constitution Abroad (Columbia University Press, 1990).

8. See, by Cutler, "To Form a Government," Foreign Affairs, 1980; and "Party Government Under the Constitution," University of Pennsylvania Law Review, December 1985 . Both are reprinted in Donald L. Robinson, ed., Reforming American Government (Westview, 1985). By Sundquist, see Constitutional Reform and Effective Government (Brookings, 1986); and "Needed: A New Political Theory for the New Era of Coalition Government in the United States," prepared for delivery at the APSA Annual Meeting, 1988, and published in Political Science Quarterly (1989).

9. See also a Symposium, entitled "Divided Government and the Politics of Constitutional Reform," in PS: Political Science \& Politics (December 1991), containing brief articles by Mark Petracca, David Mayhew, Gary Jacobson, Morris Fiorina, James Thurber, and others.

10. The device is not well exploited where constitutionalism is concerned. It presents an editorial by John Greenwald, entitled "Exploring the Constitution" (originally published in Time magazine, July 1987). Highly celebratory, it is not a sensitive or wellinformed piece of writing.

11. The analytical framework cited by the project is academic, and somewhat special even by the standards of academia. It is based on models of bargaining developed by T. C. Schelling and others. The investigators describe the project as a whole as "social scientific, not consultative." They add that it will "not be involved in advising the countries to be studied about legal and constitutional choices." It is directed by outstanding scholars, and it will draw on the excellent holdings at the University of Chicago (including one of the "top ten or twelve" Slavic collections in the country, according to the project prospectus).

12. Great Britain and Israel seem to soldier along without written constitutions, but both are deeply committed to the rule of law, and both practice constitutionalism to a high degree. If they are exceptions, they prove the rule.

13. To mention just a few examples of current American concern: How can presidents be kept from abusing the "war powers"? Do citizens have economic and social rights, and if so, how can they be secured? How can citizens hold the government of a huge nation to account for its performance? How ought responsibilities be shared among layers of a federal system, and how can such sharing be maintained?

14. George Akita, Foundations of Constitutionalism in Modern Japan (Harvard University Press, 1967).

15. Sadly, some purveyors of constitutiondrafting skills prey on this mentality. Albert $P$. Blaustein, professor of law at Rutgers University who has been a paid consultant on constitutional drafting in a number of countries, has written, "By following the United States model, all of the constitution writers after 1787 could legitimize their revolutions, their independence, their nationhood" (Phi Kappa Phi Journal, Fall 1984, p. 16). If only it were that simple.

16. My impression is confirmed by recent correspondence with Walter Murphy of Princeton, Martin Shapiro of UCal-Berkeley, William Riker of the University of Rochester, and J. Woodford Howard of Johns Hopkins, among other authorities in this field. When I wrote Murphy and Shapiro last year to ask where a student I was advising might pursue the comparative study of constitutionalism at the graduate level, both answered that there was no American university presently offering graduate-level instruction in that field.

17. Perhaps "renewal" would be a better word. Carl J. Friedrich and others in the 1930s, '40s and '50s were turning out treatises on constitutionalism (Friedrich's Constitutional Government and Democracy), criticizing the performance of the American system (William Yandell Elliott's The Need for Constitutional Reform and Thomas K. Finletter's Can Representative Government Do the $J o b ?$ ), and helping new nations to write constitutions. As an academic field, however, the study of comparative constitutionalism has lapsed since then.

18. A. E. Dick Howard, professor of law at the University of Virginia, has compiled a volume, called Democracy's Dawn: A Directory of American Initiatives on Constitutionalism, Democracy, and the Rule of Law in Central and Eastern Europe (University Press of Virginia, 1991). Concentrating on Bulgaria, Czechoslovakia, Hungary, Poland, and Romania (leaving aside Yugoslavia, Albania, the Baltics, and the Soviet republics), it devotes nearly 200 pages to a catalogue of organizations involved in this work, including government agencies, foundations, learned societies, university centers, ethnic organizations, and groups that do programs in a particular country. Appendices provide a guide to programs by country and by types of assistance (conferences, exchange programs, grants, publications, reference services, and technical assistance). Barbara Perry, political scientist from Sweet Briar College, presented a paper at the Annual Meeting of the American Political Science Association, September 1991, drawing largely on Howard's data to analyze the participants involved in constitutional efforts abroad. Her main finding is that these consultants have tended disproportionately to be males and trained in the law, rather than the social sciences.

19. In focusing on Eastern Europe, I do not mean to denigrate the valuable contribution that some Americans have made to the establishment of democratic governance in the Third World. One example is Namibia. Several Americans associated with the Lawyers Committee for Civil Rights and the Lutheran World Federation monitored the deliberation of the constitutional convention in 1989-90. The Lutherans in particular, having developed strong ties with Namibian leaders by helping them deal over the years with political trials and other forms of oppression, were able to offer useful counsel about electoral systems and to explain how rights work in terms the Namibians could understand. (Source: Ralston Deffenbaugh, Harvardtrained lawyer who now heads the Lutheran Immigration and Relief Service [LIRS] in New York.) Such work, built on carefully laid foundations of mutual trust, goes far beyond "technical assistance."

20. Shepard Forman, "Strategy for Private Philanthropy in Promoting the Development of Democratic Institutions in Eastern Europe,' pp. 4-9. Forman's paper was prepared for presentation at the Annual Research Conference of the Association for Public Policy Analysis and Management (APPAM), October 24-27, 1991, in Washington, D.C.

21. LC:CRS is not unique in providing material support. The Center for Democracy, with a small grant from the National Endowment for Democracy, has assembled and distributed Libraries of Democracy (packets of books, articles, videos and other materials) for distribution to organizations in Central and Eastern Europe.

22. Louis Fisher, of the LC:CRS staff, an outstanding political scientist, has joined several of these delegations. People at CEELI tell me that Fisher's intimate knowledge of how American political institutions developed and how they now operate is intensely interesting to politicians, lawyers, and law students in places like Bulgaria and Romania.

23. Note that the first constitutions of the American states, in reaction against British "tyranny," placed dominant power in the legislatures. It wasn't until the mid-1780s that the American doctrine of separation of powers began to insist on checking the power of legislative assemblies, as well as the other branches.

24. For financial support, CEELI credits, besides the ABA, the National Endowment for Democracy, United States Information Agency and the International Academy of 
Trial Lawyers. Because its experts work pro bono, because its paid staff is small and works from a modest suite in the ABA building in Washington, and because hospitality costs in the host countries are minimal, CEELI has been able to operate inexpensively.

25. In an article in The University of Chicago Law Review (Spring 1991), entitled "Constitutional Politics in Poland: A Report on the Constitutional Committee of the
Polish Parliament," Rapaczynski suggests that the effort to draft a constitution in 1990 may have been premature (see, esp., pp. 606-08, 630-31).

26. Founded at the law school in Bologna, Italy, it recently moved to Venice. J. Woodford Howard, Jr., of Johns Hopkins University, tells me that American legal scholars have discussed joining this effort, but no law school has been willing to take the lead.

\section{About the Author}

Donald L. Robinson is Sylvia D'Lugasch Bauman Professor of Government and American Studies at Smith College.

The Pacific Century: A Television Series

Continued from page 237

We tried to make this an intellectually ambitious series that would also be both emotionally compelling and visually engaging. American students typically lack visual and social images of Asia that can support a more substantive study of the several countries in the region. To help provide American viewers with these significant images, our producers traveled to 12 different countries in the Pacific, filming a cross-section of people from very different walks of life; from a powerful politician in Japan to a group of poor nurses in the Philippines, from a women's rights activist in South Korea to a textile magnate in Hong Kong.

It is our hope and expectation that these ten one-hour programs of THE PACIFIC CENTURY will foster more comprehensive understanding on campuses about the Asia-Pacific region and relations with the United States. We are particularly interested in seeing that the individual programs are used by faculty to encourage knowledgeable debate in courses in comparative politics, international relations, public policy, and as a comparative base study for American politics.

THE PACIFIC CENTURY video series will air on PBS during prime time in fall 1992. The ten programs include:

"The Two Coasts of China: Asia and the Challenge of the West"- treats the collision of East and West in the early 19th century;

"Meiji: Asia's Response to the West"-Japan is the first of the underdeveloped nations to modernize and gain power;

"From the Barrel of a Gun"-the lives of Vietnam's Ho Chi Minh and Indonesia's Sukarno reflect the nationalist movement in those former colonies;

"Writers and Revolutionaries"-Chinese writer Lu Xun and Japanese philosopher Kita Ikki are profiled as intellectuals who play a significant role in promoting social change in their homelands;

"Reinventing Japan"- -examines the transformation during the American occupation after WWII;

"Inside Japan, Inc."-considers the political, historical and cultural roots of Japan's post-war economic miracle;

"Big Business and the Ghost of Confucius"-looks at Asia's newly industrialized countries-Taiwan, South Korea and Singapore;

"The Fight for Democracy"-explores expectations among Asian people for greater political freedom as exemplified by the Republic of Korea;

"Sentimental Imperialists: America in Asia"-looks at American involvement with China and the Philippines; and

"The Pacific Century: The Future of the Pacific Basin"-explores common problems, including pollution, overpopulation, trade friction and immigration shared by the entire region.

If you would like to see a preview videocassette, you may call 1-800-LEARNER. This same contact number handles orders for the complete series ( $\$ 275$ on VHS, or $\$ 29.95$ for a single program).

The print resources that accompany the video series include a new text, Pacific Century: The Emergence of Modern Pacific Asia, by Mark Borthwick, et al.; a study guide, The Pacific Century Study Guide, by Mark Borthwick and Gill Latz; and The Pacific Century Faculty Guide, by Mark Borthwick and Gil Latz. All of these books are available by calling Westview Press at (303) 444-3541. A companion tradebook, The Pacific Century, by Frank Gibney, offers a personal overview of the history and themes of the Pacific basin region, and will be available from Scribner's in early fall. 